\title{
IDENTIFICATION OF BIOACTIVE COMPOUNDS IN FLOWER OF TABERNAEMONTANA DIVARICATA (L.) USING GAS CHROMATOGRAPHY-MASS SPECTROMETRY ANALYSIS
}

\author{
KALAIMAGAL C* \\ Department of Biotechnology, Marudupandiyar College of Arts and Science, Thanjavur, Tamil Nadu, India. Email: kalai.andal@gmail.com
} Received: 12 June 2019, Revised and Accepted: 13 July 2019

\begin{abstract}
Objective: Herbs are a key resource with therapeutic properties. Nowadays, there is a focus on the identification of bioactive compounds with the ability to act against various disorders.

Methods: In the present study, gas chromatography-mass spectrometry analysis was conducted to determine the occurrence of different phytochemical compounds in ethanolic flower extract of Tabernaemontana divaricata (L.).
\end{abstract}

Results: The ethanol extract of flower revealed the presence of several bioactive compounds such as n-hexadecanoic acid, squalene, Vitamin D3, Vitamin A aldehyde, desulfosinigrin, and Urs-12-en-24-oic acid, 3-oxo-, methyl ester, (+)-.

Conclusion: The perceived compounds from ethanolic extract of flower have diverse beneficial properties such as antimicrobial, antioxidant, cancer anticipatory effect, pesticide, and antiarthritic.

Keywords: Tabernaemontana divaricata (L.), Gas chromatography-mass spectrometry analysis, Bioactive compounds.

(C) 2019 The Authors. Published by Innovare Academic Sciences Pvt Ltd. This is an open access article under the CC BY license (http://creativecommons. org/licenses/by/4. 0/) DOI: http://dx.doi.org/10.22159/ajpcr.2019.v12i9.34559

\section{INTRODUCTION}

Plants are posh bequest to every individual because of the presence of curative possessions. Medicinal plants can act as wealthy mine of phytochemicals (secondary metabolites) with diverging natal actions [1]. These compounds defend human being through the action against unremitting and contagious disorders [2-4].

The World Health Organization stated that above $80 \%$ of populace depend on conventional basis plant drugs for their principal wellbeing penury [5-7]. Herbal medications are inoffensive than synthetic medicines since in attendance with the phytochemical constituents in herbal extract that intent biochemical path [8].

At present, these plant-based drugs come to attention notably in developing countries for the treatment of copious diseases owing to its certainty that green linctus is secure, economic, simply accessible as well as few side effects. As a consequence of these reasons, awareness about its exploitation can be spreaded throughout the world [9].

Disposition of various dynamic phytochemical compounds in these green medicinal plants has bestowed origin for maximum activity containing drugs. Most significant chemical active components of shrubs are alkaloids, flavonoids, and tannin likewise some phenolic compounds. Right now, the exigency for herbal products has augmented drastically. Hence, nowadays, pharmaceutical companies are also produce health-care products from therapeutic herbs [2] which have the ability to provide naturally active compounds and it can act against numerous syndromes [10].

In India, one of the ornamental as well as shrine plants is Tabernaemontana divaricata (L.), it belongs to Apocynaceae family. It has dichotomous branch containing herb, or small tree is extensively dispersed all over in India, Bangladesh, and some elements of South East Asia. It engenders gorgeous white-colored aroma flowers and may become visible intermittently during the year. The leaves are sleek, hefty, and deep green in color. It holds variety of beneficial actions such as antimicrobial, antioxidant along with antidiabetic properties [11-13].

Gas chromatography-mass spectrometry (GC-MS) is the better process to find the biochemical components of long-chain hydrocarbons, volatile essential oil, fatty acids, lipids, alkaloids, steroids, amino, nitro compounds, alcohols, esters, etc. [14,15]. Normally, GC-MS is used for detection and enumeration of compounds in various extracted samples. The known compound spectrum can be matched with unknown components in complex mix. This analysis used to detach diverse compounds in the sample based on their wavering [16]. From the literatures, it is evident to analyze herbal value of the plant T. divaricata (L.). In this study, GC-MS technique was applied to find the presence of several bioactive compounds in the ethanolic extract of $T$. divaricata (L.) flowers to give better pharmacological activities.

\section{MATERIALS AND METHODS}

\section{Plant material}

T. divaricata (L.) plant was identified with the help of book and literature references [17-19], and the herbarium was deposited in the Department of Biotechnology, Marudupandiyar College of Arts and Science, Thanjavur, Tamil Nadu, India. T. divaricata (L.) flowers (double layer flowering plant variety) were gathered in and around area of Thanjavur, Tamil Nadu, India. Collected flowers were cleansed and dried in shadow for 2 weeks. Dried plant material was pulverized with electrical beater into fine powder and then utilized to prepare extracts.

\section{Preparation of extract for GC-MS}

$25 \mathrm{~g}$ flower powder was treated with $50 \mathrm{ml}$ of ethanol for $12 \mathrm{~h}$ and sieved by means of Whatman Filter Paper No. 41 among sodium sulfate (2 g). Beforehand this separation, filter paper along with $\mathrm{Na}_{2} \mathrm{SO}_{4}$ was damped with 95\% ethanol. This filtration used for the elimination of sediments and water in the filtrate. The filtrate was abridged by bubbling nitrogen gas. $2 \mu \mathrm{l}$ of extract was injected into GC-MS apparatus [20]. 


\section{GC-MS program}

GC-MS technique was performed in a GC Clarus 500 Perkin Elmer system. GC-MS operated using the following conditions: Column: Elite$5 \mathrm{MS}(30 \times 0.25 \mathrm{~mm} \times 0.25 \mathrm{~m} \mathrm{df}$, made up of $5 \%$ diphenyl $/ 95 \%$ dimethyl polysiloxane), electron energy - $70 \mathrm{eV}$; helium was utilized as hauler gas and at a incessant surge of $1 \mathrm{ml} / \mathrm{min} .2 \mu \mathrm{l}$ of injection volume was employed (split ratio of $10: 1$ ). The temperature of injector was $250^{\circ} \mathrm{C}$; temperature of inlet and source was $200^{\circ} \mathrm{C}$. The oven temperature was encoded up to $200^{\circ} \mathrm{C}$ at the rate of $10^{\circ} \mathrm{C} / \mathrm{min}$ (no hold), to $5^{\circ} \mathrm{C} / \mathrm{min}-9 \mathrm{~min}$ hold up to $280^{\circ} \mathrm{C}$. Mass spectra were taken at $70 \mathrm{eV}$; mass scan $(\mathrm{m} / \mathrm{z})$ fragments were obtained from 45 to $450 \mathrm{Da}$. Total working time of GC and MS was 36 min [21].

\section{Identification of components}

GC-MS spectrum was interpreted with the database of National Institute of Standard and Technology (NIST) containing above 62,000 paradigms. Spectrum of familiar compounds accumulated in the NIST library and unknown components spectrum identified from GC-MS method was correlated. After comparison, name, molecular weight (MW), and structure of the tested components were ascertained [16].

\section{RESULTS AND DISCUSSION}

\section{GC-MS analysis}

Through GC-MS study, 16 active compounds were determined in the flower extract of T. divaricata (L.). Identified components with their molecular formula, MW, retention time (RT), and concentration (\% peak area) are specified in Table 1 as the same GC-MS chromatogram of above compounds perceived is shown in Fig. 1.

Most phytochemicals have antioxidant capacity and safeguard our cells against oxidative damage and decrease the threat of emerging definite types of cancer. Antioxidants retard the feat of free radicals which have been responsible for the pathogenesis of copious syndromes $[22,23]$.

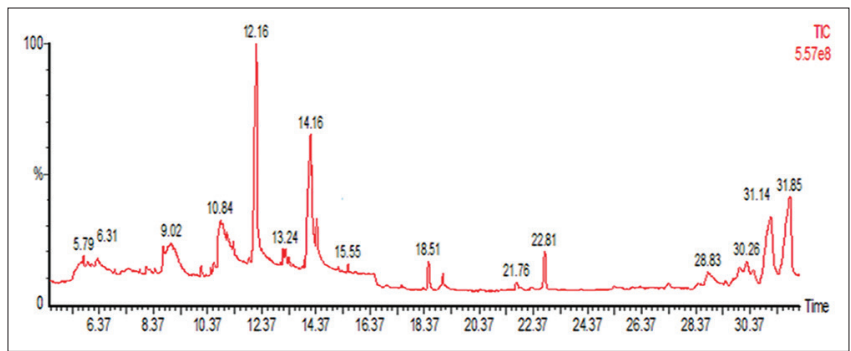

Fig. 1: Gas chromatography-mass spectrometry chromatogram for ethanolic flower extract of Tabernaemontana divaricata $(\mathrm{L}$.
Vitamin D3 is a liposoluble vitamin. Very few dietary supplements possess this vitamin naturally also fabricated by the skin when rendered to the sunlight. Right now, Vitamin D3 deficiency is a big problem because of the vast proportion of world civilization. In both smokers and non-smokers, low level of this vitamin raises propensity to respiratory infections and destitute mineralization of the skeleton owing to calcium besides phosphate diminution [24,25]. This kind of calcium depletion is the starting point for bone-related complaints. It has the capacity to act against cancer as well as decrease blood pressure and increase insulin secretion [26-28]. For these reasons, Vitamin D3 demand is still increasing.

Vitamin A aldehyde is otherwise known as retinal. Huge amount of compounds can come under the category of Vitamin A. Retinol and retinal are called as preformed Vitamin A. Deficiency of Vitamin A is linked with severe physical tribulations such as night blindness [29], complexity in epithelium formation [30], elevated threat in respiratory passages [31], and play a role as antioxidant [32,33].

1,6,10-Dodecatriene, 7,11-dimethyl-3-methylene-, (Z)- is a sesquiterpene and it has anti-tumor, antibacterial, anti-inflammatory properties [34]. Alpha-D-Glucopyranoside, 0-à-D-glucopyranosyl-(1. fwdarw.3)-á-D-, fructofuranosyl is a sugar molecule; furthermore, it possesses anti-inflammatory and diuretic effect [35]. Palmitic acid, linoleic acid, cholestan-3-ol, 2-methylene-, (3á,5à)-, and 1-Heptatriacotanol acquires antioxidant, anti-inflammatory hypocholesterolemic, antimicrobial, and anticancer properties [36,37]

Cyclopropane tetradecanoicacid, 2-octyl-, methyl ester, has antimicrobial activity [38]. 9,12,15-Octadecatrienoic acid, 2,3- bis(acetyloxy)propyl ester, $(\mathrm{Z}, \mathrm{Z}, \mathrm{Z})$ - is an unsaturated fatty acid ester compound which possesses anti-inflammatory, hypocholesterolemic, cancer preventive, hepatoprotective, nematicide, antihistaminic, antieczemic, antiacne, antiarthritic, and antiandrogenic activities [39]. Terpenoids can act as controller of metabolism and play a defensive role as antioxidants along with it acquires antimicrobial, antiallergic, and anti-inflammatory activity [40]. Likewise, triterpene squalene retains antimicrobial, antioxidant as well as anticancer activities [41,42]. Desulphosinigrin holds antioxidant capacity and also acts against urinary tract infections $[35,43]$.

Swamy et al. [44] reported the GC-MS analysis of methanolic leaf extract of Alstonia scholaris (Apocynaceae family). Through this method, only nine compounds were identified. Similarly, Papitha et al. [45] investigated that chemical compounds present in chloroform extract of leaves and flowers of Spermadictyon suaveolens Roxb., and they got ten and eight compounds, respectively. RT and peak area percentage was slightly matched with squalene compound recognized from methanolic extract of Adiantum capillus-veneris L. [6]. Kalaivani

Table 1: RT, MW, and peaks of various components identified in flower by GC-MS

\begin{tabular}{|c|c|c|c|c|c|}
\hline S. No. & RT & Name of the compound & Molecular formula & MW & Peak area \% \\
\hline 1. & 5.79 & 1,6,10-Dodecatriene, 7,11-dimethyl-3-methylene-, (Z)- & $\mathrm{C}_{15} \mathrm{H}_{24}$ & 204 & 4.55 \\
\hline 2. & 6.31 & Cyclohexanepropanoic acid, 3-oxo-, methyl ester & $\mathrm{C}_{10}^{15} \mathrm{H}_{16}^{24} \mathrm{O}_{3}$ & 184 & 5.94 \\
\hline 3. & 9.02 & a-D-Glucopyranoside, 0-à-D-glucopyranosyl-(1.fwdarw. 3)-á-D-fructofuranosyl & $\mathrm{C}_{18}^{10} \mathrm{H}_{32} \mathrm{O}_{16}$ & 504 & 10.80 \\
\hline 4. & 10.11 & Vitamin D3 & $\mathrm{C}_{27}^{18} \mathrm{H}_{44}^{32} \mathrm{O}$ & 384 & 0.43 \\
\hline 5. & 10.84 & Desulphosinigrin & $\mathrm{C}_{10}^{27} \mathrm{H}_{17}^{4} \mathrm{NO}_{6} \mathrm{~S}$ & 279 & 8.08 \\
\hline 6. & 11.06 & Lactose & $\mathrm{C}_{12}{ }^{10} \mathrm{H}_{22} \mathrm{O}_{11}{ }^{6}$ & 342 & 4.11 \\
\hline 7. & 12.16 & n-Hexadecanoic acid & $\mathrm{C}_{16} \mathrm{H}_{32} \mathrm{O}_{2}$ & 256 & 16.16 \\
\hline 9. & 14.16 & 9,12-Octadecadienoic acid (Z, Z)- & $\mathrm{C}_{18}^{26} \mathrm{H}_{32}^{50} \mathrm{O}_{2}^{2}$ & 280 & 15.49 \\
\hline 10. & 18.51 & 4-(4-Methyl-2-biphenylyloxy) phthalonitrile & $\mathrm{C}_{21}^{18} \mathrm{H}_{14}^{32} \mathrm{~N}_{2}^{2} \mathrm{O}$ & 310 & 1.40 \\
\hline 11. & 21.76 & 9,12,15-Octadecatrienoic acid, 2,3-bis (acetyloxy) propyl ester, (Z, Z, Z)- & $\mathrm{C}_{25}^{21} \mathrm{H}_{40}^{14} \mathrm{O}_{6}^{2}$ & 436 & 0.47 \\
\hline 12. & 22.81 & Squalene & $\mathrm{C}_{30}^{25} \mathrm{H}_{50}$ & 410 & 2.29 \\
\hline 13. & 28.83 & Cholestan-3-ol, 2-methylene-, (3á,5à)- & $\mathrm{C}_{28}^{30} \mathrm{H}_{48}^{50} \mathrm{O}$ & 400 & 3.55 \\
\hline 14. & 30.26 & Vitamin A aldehyde & $\mathrm{C}_{20}^{28} \mathrm{H}_{28}^{48} \mathrm{O}$ & 284 & 2.80 \\
\hline 15. & 31.14 & 1-Heptatriacotanol & $\mathrm{C}_{37}^{20} \mathrm{H}_{76}^{28} \mathrm{O}$ & 536 & 11.36 \\
\hline 16. & 31.85 & Urs-12-en-24-oic acid, 3-oxo-, methyl ester, (+)- & $\mathrm{C}_{31}^{37} \mathrm{H}_{48} \mathrm{O}_{3}$ & 468 & 11.72 \\
\hline
\end{tabular}

RT: Retention time, MW: Molecular weight, GC-MS: Gas chromatography-mass spectrometry 
et al. [46] examined and detected thirteen compounds from ethanolic leaf extract of Andrographis paniculata using GC-MS technique, and percentage of peak area was very low in some compounds such as n-Hexadecanoic acid (4.44), 9,12-Octadecadienoic acid (Z,Z)- (0.86), and squalene (0.87).

By comparing with the literatures stated above, the present work that means the ethanolic flower extract of $T$. divaricata (L.) exhibits sixteen different phytochemical compounds. Hence, it can be used for pharmacological activities.

\section{CONCLUSION}

The current investigation concludes that the flower has engendered numerous phytochemical compounds with natal action. Because of this reason, it can be used for the improvement of novel drugs to treat several disorders. The elucidation of specific compound is responsible for treating particular ailment which will be helpful for pharmaceutical industries to synthesize those medications in the future.

\section{AUTHOR CONTRIBUTION}

Author contributed to the paper.

\section{CONFLICTS OF INTEREST}

No conflicts of interest.

\section{REFERENCES}

1. Asha KR, Priyanga S, Hemmalakshmi S, Devaki K. GC-MS analysis of the ethanolic extract of the whole plant Drosera indica L. J Pharmacogn Phytochem Res 2017;9:685-8.

2. Banakar P, Jayaraj M. GC-MS analysis of bioactive compounds from ethanolic leaf extract of Waltheria indica Linn. And their pharmacological activities. Int J Pharm Sci Res 2018;9:2005-10.

3. Mtunzi FM, Ejidike IP, Matamela T, Dikio E, Klink MJ. Phytochemical profiling, antioxidant and antibacterial activities of leaf extracts from Rhus leptodictya. Int J Pharmacogn Phytochem Res 2017;9:1090-9.

4. Sivakrishnan S, Pradeepraj D. Gas chromatography mass spectrocopy analysis of ethanolic extract of leaves of Cordia oblique Willd. Asian J Pharm Clin Res 2019;12:110-2.

5. Shunmugapriya K, Kalavathy U. GC-MS analysis of bioactive constituents of Rauwolfia densiflora (Wall) Benth. Ex Hk. F. Int J Appl Biol Pharm Technol 2012;3:179-83.

6. Kumar S, Samydurai P, Ramakrishnan R, Nagarajan N. Gas chromatography and mass spectrometry analysis of bioactive constituents of Adiantum capillus-veneris L. Int J Pharm Pharm Sci 2014;6:60-3.

7. Kalva S, Raghunandan N. Preliminary phytochemical screening and antimicrobial activity of dried flowers of Adenium obesum. Int J Curr Pharm Res 2019;11:34-6.

8. Dhivya R, Manimegalai K. Preliminary phytochemical screening and GC-MS profiling of ethanolic flower extract of Calotropis gigantea Linn. (Apocynaceae). J Pharmacogn Phytochem 2013;2:28-32.

9. Zaidan MR, Noor Rain A, Badrul AR, Adlin A, Norazah A, Zakiah I, et al. In vitro screening of five local medicinal plants for antibacterial activity using disc diffusion method. Trop Biomed 2005;22:165-70.

10. Nishaa S, Vishnupriya M, Sasikumar JM, Gopalakrishnan VK. Phytochemical screening and GC-MS analysis of ethanolic extract of rhizomes of Maranta arundinacea L. Res J Pharm Biol Chem Sci 2013:4:52-9.

11. Ashikur MD, Rahman MD. Evauation of anibacterial activity of study of leaves of Tabernaemontana divaricata (L). Int Res J Pharm 2011;2:123-7.

12. Rumzhum NN, Rahman MM, Kazal MK. Antioxidant and cytotoxic potential of methanol extract of Tabernaemontana divaricata leaves. Int Curr Pharm J 2012;1:27-31.

13. Rahman MM, Sayeed MA, Biplab KP, Siddique SA. Antidiabetic and cytotoxic activities of methanolic extract of Tabernaemontana divaricata (L.) leaves in alloxan induced mice. Asian J Pharm Clin Res 2012;5:49-52.

14. Xie Z, Liu Q, Liang Z, Zhao M, Yu X, Yang D, et al. The GC/MS analysis of volatile components extracted by different methods from exocarpium citri grandis. J Anal Methods Chem 2013;2013:1-8.
15. Hassanpouraghdam MB. Flowerhead volatile oil composition of soilless culture-grown Chrysanthemum balsamita L. Nat Prod Res 2009;23:672-7.

16. Arirudran B, Oswin MA, Balabhaskar R. GC/MS determination of bioactive components from Cuminum cyminum L. World J Pharm Res 2018;7:1671-83.

17. Warrier PK. Indian Medicinal Plants: A Compendium of 500 Species. Vol. 5. New York: Orient Longman Pvt., Ltd,; 1996. p. 232-4.

18. Kam TS, Loh KY, Wei C. Conophylline and conophyllidine: New dimeric alkaloids from Tabernaemontana divaricata. J Nat Prod 1993;56:1865-71.

19. Kam TS, Pang HS, Lim TM. Biologically active indole and bisindole alkaloids from Tabernaemontana divaricata. Org Biomol Chem 2003;1:1292-7.

20. Paranthaman R, Kumar PP, Kumaravel S. GC-MS Analysis of phytochemicals and simultaneous determination of flavonoids in Amaranthus caudatus (Sirukeerai) by RP-HPLC. J Anal Bioanal Tech 2012;3:147.

21. Kumaravel S, Kumar PP, Vasuki P. GC-MS Study on Microbial degradation of Lindane. Int J Appl Chem 2010;6:363-6.

22. Coruh N, Celep AS, Ozgokce F. Antioxidant properties of Prangos ferulacea (L.) Lindl., Chaerophyllum macropodum Boiss. and Heracleum persicum Desf. from Apiaceae family used as food in Eastern Anatolia and their inhibitory effects on glutathione-S-transferase. Food Chem 2007:100:1237-42.

23. Dasgupta N, De B. Antioxidant activity of Piper betle L. leaf extract in vitro. Food Chem 2004;88:219-24.

24. Buonfiglio LG, Cano M, Pezzulo AA, Vanegas Calderon OG, Zabner J, Gerke $\mathrm{AK}$, et al. Effect of Vitamin $\mathrm{D}_{3}$ on the antimicrobial activity of human airway surface liquid: Preliminary results of a randomised placebo-controlled double-blind trial. BMJ Open Respir Res 2017;4:e211

25. Gil Á, Plaza-Diaz J, Mesa MD. Vitamin D: Classic and novel actions. Ann Nutr Metab 2018;72:87-95.

26. Jeon SM, Shin EA. Exploring Vitamin D metabolism and function in cancer. Exp Mol Med 2018;50:20.

27. Jeong HY, Park KM, Lee MJ, Yang DH, Kim SH, Lee SY, et al. Vitamin D and hypertension. Electrolyte Blood Press 2017;15:1-1.

28. Acharya A, Halemani SS. Role of Vitamin D in diabetes mellitus. Int J Pharm Sci Res 2016;7:1881-8.

29. Bennasir H, Sridhar S, Abdel-Razek TT. Vitamin A from physiology to disease prevention. Int J Pharm Sci Rev Res 2010;1:68-73.

30. Huang Z, Liu Y, Qi G, Brand D, Zheng SG. Role of Vitamin A in the immune system. J Clin Med 2018;7:e28.

31. Timoneda J, Rodríguez-Fernández L, Zaragozá R, Marín MP, Cabezuelo MT, Torres L, et al. Vitamin A deficiency and the lung. Nutrients 2018;10:e1132.

32. Mohammed GJ, Omran AM, Hussein HM. Antibacterial and phytochemical analysis of Piper nigrum using gas chromatographymass spectrum and fourier-transform infrared spectroscopy. Int $\mathrm{J}$ Pharmacogn Phytochem Res 2016;8:977-96.

33. Li S, Chen G, Zhang C, Wu M, Wu S, Liu Q. Research progress of natural antioxidants in foods for the treatment of diseases. Food Sci Hum Wellness 2014;3:110-6.

34. Gopinath S, Sakthidevi G, Muthukumaraswamy S, Mohan VR. GCMS analysis of bioactive constituents of Hypericum mysorense (Hypericaceae). J Curr Chem Pharm Sci 2013;3:6-15

35. Hussein HM. Analysis of trace heavy metals and volatile chemical compounds of Lepidium sativum using atomic absorption spectroscopy, gas chromatography-mass spectrometric and fourier-transform infrared spectroscopy. Res J Pharm Biol Chem Sci 2016;7:2529-55.

36. Madhavan M. Phytochemical constituents of leaves of Spatholobus parviflorus a rare threatened climber of South India. Int J Pharmacogn Phytochem Res 2015;7:991-4.

37. Al-Rubaye AF, Kaizal AF, Hameed IH. Phytochemical screening of methanolic leaves extract of Malva sylvestris. Int J Pharmacogn Phytochem Res 2017;9:537-52.

38. Srivastava R, Mukerjee A, Verma A. GC-MS analysis of phytocomponents in, pet ether fraction of Wrightia tinctoria seed. Pharmacogn J 2015;7:249-53.

39. Egbung GE, Anosike C, Utu-Baku AB, Ogar I, Udo NN. Phytochemical evaluation and GC-MS analysis of Hyptis verticillata cultivated in Calabar Cross River State, Nigeria. Int J Biol Chem Sci 2017:11:2548-59.

40. Wagner KH, Elmadfa I. Biological relevance of terpenoids. Overview focusing on mono-, di- and tetraterpenes. Ann Nutr Metab 2003;47:95-106. 
41. Sasikala K, Mohan SC. Total phenolic, flavanoid contents and GCMS analysis of Canthium coromandelicum leaves extract. Int J Pharm Pharm Sci 2014;6:379-81.

42. Jothi RS, Uthayakumari F, Bharathy V. Phytochemical profile of leaf samples of subspecies of Senna italica Mill. Biosci Discov 2015;6:106-11.

43. Vinothkanna A, Manivannan P, Muralitharan G, Sekar S. In silico probing of anti-arthritic potential of traditionally fermented ayurvedic polyherbal product balarishta reveals lupeol and desulphosinigrin as efficient interacting components with urec. Int $\mathrm{J}$ Pharm Pharm Sci 2014;6:469-75.
44. Swamy NT, Rosaiah G, Babu K, Kumar KV. A study on phytochemical composition, GC-MS analysis and anti-microbial potential of methanolic leaf extract of Alstonia scholaris (L.) R. BR. Int J Pharm Sci Res 2019;10:747-55.

45. Papitha R, Ravi L, Selvaraj CI. Phytochemical studies and GC-MS analysis of Spermadictyon suaveolens Roxb. Int J Pharm Pharm Sci 2017:9:143-9.

46. Kalaivani CS, Sathish SS, Janakiraman N, Johnson M. GC-MS studies on Andrographis paniculata (Burm. f.) Wall. Ex Nees a medicinally important plant. Int J Med Arom Plants 2012;2:69-74. 